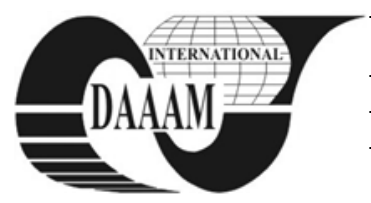

Annals of DAAAM for 2011 \& Proceedings of the 22nd International DAAAM Symposium, Volume 22, No. 1, ISSN 1726-9679 ISBN 978-3-901509-83-4, Editor B. Katalinic, Published by DAAAM International, Vienna, Austria, EU, 2011 Make Harmony between Technology and Nature, and Your Mind will Fly Free as a Bird Annals \& Proceedings of DAAAM International 2011

\title{
FINANCIAL MANAGEMENT OF SMALL AND MEDIUM SIZED ENTERPRISES IN SLOVAKIA DURING FINANCIAL CRISIS
}

\author{
BESTVINOVA, V[iera]; CAMPBELL, J[ana]; HOMOKYOVA, M[aria] \& HORVATHOVA, M[artina]
}

\begin{abstract}
The focus of this paper is on the impact of the global financial and economic crisis on small and medium sized enterprises (SMEs). After defining SMEs and emphases of the important role of financial management in the companies of this size, this paper recommends various ways to improve financial management in Slovak SMEs in the global financial and economic crisis.
\end{abstract}

Key words: small and medium sized enterprises (SMEs), global financial and economic crisis, financial management

\section{INTRODUCTION}

Many economists consider the financial and economic crisis from 2007 to the present to be the worst crisis since the Great Depression of the 1930s. Even though this crisis started off as a subprime mortgage crisis in the US, it quickly turned into a global financial crisis and later into a global economic crisis that had a negative impact also on the business environment of non-financial firms. Many enterprises had to reconsider their position in the changed environment and accept unpopular arrangements to survive the crisis. The crisis led to a lower demand for products and services, pressure to lower prices, decrease in sales, an increase in unemployment and limited offer of external financing. Management of small and medium sized companies had to take proactive steps to survive this critical time. Even though SMEs are more flexible than large companies and can react faster, they are also more sensitive to changes in product/service demand, supply network and the financial sector, and can suffer from crisis faster than large enterprises. In order to survive the crisis and to overcome negative changes in the business environment management of small and medium sized companies must be flexible, innovative, and ready to adjust to new conditions.

\section{SMALL AND MEDIUM SIZED ENTERPRISES AND THEIR IMPORTANCE IN SLOVAK ECONOMICS}

Definitions of small and medium sized enterprises vary from country to country. SMEs are mostly defined with help of quantitative measures (number of employees, revenues, owner's equity, etc.).

Slovakia has adopted the SME definition of the European Commission which, per recommendation 2003/361/EC, effective January 1, 2005, states that SMEs are autonomous enterprises which employ fewer than 250 persons, and which have either an annual turnover not exceeding 50 million euro, or an annual balance sheet total not exceeding 43 million euro. Within this category, small enterprises are defined as autonomous enterprises, which employ fewer than 50 persons and whose annual turnover or annual balance sheet total does not exceed 10 million euro. Micro enterprises are defined as autonomous enterprises, which employ fewer than 10 persons and whose annual turnover or annual balance sheet total does not exceed 2 million euro (see tab. 1).

\begin{tabular}{|c|c|c|c|c|}
\hline $\begin{array}{c}\text { Enterprise } \\
\text { category }\end{array}$ & Headcount & Turnover & or & $\begin{array}{c}\text { Balance } \\
\text { sheet total }\end{array}$ \\
\hline $\begin{array}{l}\text { medium- } \\
\text { sized }\end{array}$ & $<250$ & $\leq € 50 \mathrm{mil}$ & & $\leq € 43$ mil. \\
\hline small & $<50$ & $\leq € 10 \mathrm{mil}$ & & $\leq € 10$ mil. \\
\hline micro & $<10$ & $\leq € 2$ mil. & & $\leq € 2$ mil. \\
\hline
\end{tabular}

Tab. 1. SME definition per European Comission

SMEs play an important role in the economy of countries with a developed private sector and competitive markets. They are considered to be the engine of economic growth and a major source of technological innovation and new products. They increase competitiveness and efficiency in markets and are often more flexible than large firms in adapting to new customer requirements, facilitating workforce changes and implementing new equipment and techniques. SMEs are the largest providers of employment and play a major role in removing regional and sector imbalances in the economy.

The importance and influence of SMEs is prominent in the Slovak economy, too. Constituting $99,9 \%$ of all enterprises in Slovakia, SMEs take a major share of employment, almost $70 \%$. Most SMEs are involved in the retail and service industries (77 432), in manufacturing (13 011), and in construction (9 723). They also represent an important $43,1 \%$ share of GDP production and participate with $38,7 \%$ on Slovak export. (http://www.nadsme.sk/files/Stav_MSP_2009_1.pdf)

The critical role of the SMEs is illustrated in figure 1.

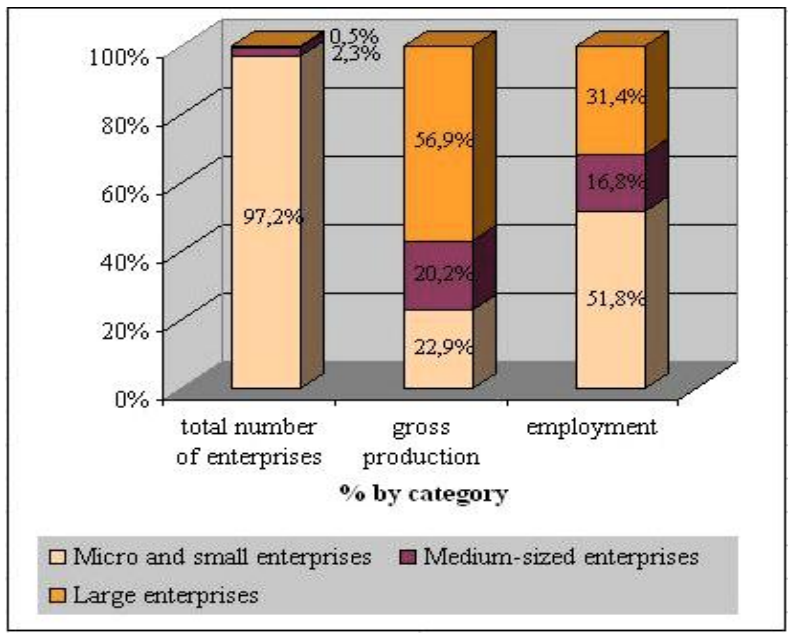

Fig. 1. Importance of small and medium-sized enterprises

\section{ROLE OF FINANCIAL MANAGEMENT IN SMALL AND MEDIUM SIZED ENTERPRISES}

Because of their size, SMEs are considered to have higher risk than larger companies. Due to the inherent vulnerability of their size, a general inability to self-fund, a smaller client-base, 
a lack of collateral or credit history, and so on, SMEs tend to go out of business or bankrupt more often than large companies. A key tool for helping SMEs survive in an ever-changing, highly competitive environment, is effective financial management.

Financial management may be defined as a subsystem of overall company management focused on managing financial processes (financial planning, financial decision-making, organization of financial processes, and financial analysis and control), and with the goal of maximizing shareholder value. The main tasks of financial management are to obtain requisite financing, to allocate finances effectively, and to determine the company's profit sharing plan. (Fetisovova et al., 2004) While financial management is critical task for any size and type of company, it is especially critical for SMEs.

Based on our research, we found that the crisis had a negative impact on more than half of interviewed SMEs. Most companies felt this impact at the beginning of 2009. Over 50\% of companies felt like the crisis had a major influence on their activities. They noticed significant decrease of revenues and limited access to external financing, especially credit financing. Some felt a pressure on price dropping, too. Lower return on investment caused problems with repayment of credit. Some companies became insolvent and had to use credit to current account, or to increase owner's equity to solve this problem. It became more difficult for small companies to get bank approval of new credit. Only a limited number of SMEs were able to get financing through SZRB (Slovak guarantee and development bank), EXIM Bank, and micro-loan program.

\section{RECOMMENDATIONS FOR FINANCIAL MANAGEMENT OF SMALL AND MEDIUM SIZED ENTERPRISES IN SLOVAKIA DURING FINANCIAL CRISIS}

In the current economic literature, there is a debate on the best practices for companies' financial management in a global financial and economic crisis. Based on our research we have following recommendations for financial management of Slovak SMEs:

1. During the crisis, it is important for SMEs to reinforce long term planing and to create and implement appropriate corporate strategy and financial strategy oriented to the primary company goal of maximizing shareholder value. Corporate strategy involves a company's choice of business, markets, and activities, and thus defines the overall scope and direction of the business. Financial strategy is one of several functional strategies. It supports corporate strategy and adds financial aspects to all strategic decisions. Financial strategy helps to evaluate the available operational alternatives, and helps to monitor the implemented decisions. Such valuation and monitoring of operating decisions is important for increasing expected cash flow for the company.

2. To be permanently ready to cope with financial and economic crisis, SMEs need to monitor the economic environment and recognize any warning signals of critical changes in their environment. Not only do they need to pay attention to the comments and estimates of various rating agencies and international banks, but also they need to analyze the financial health of their suppliers, distributors, and customers. Results of this monitoring need to be transformed into key variables for the planning process.

3. SMEs should also increase focus on cash-flow management. In order to survive the crisis, SMEs need to stay solvent and to have adequate liquidity. This can be achieved by intensive collection of receivables, reevaluation of business terms with suppliers and customers, monitoring of financial health of creditors and clients, management of working capital, and restructuring of debt.
Slovak government has taken various measures to help SMEs overcome the financial crisis. There are financial programs available to SMEs, which support innovations and technology transfer with the goal to achieve higher energy efficiency, to increase the effectivity of production, and to lower ecological impact. SMEs can apply for financial help through an operational program called "Competitiveness and Economic Growth," or through founding programs sponsored by the European Union; for example, the Competitiveness and Innovation Framework Program, or the Seventh Framework Program for Research and Technological Development. (***, 2011)

4. Most SMEs use financial ratios to evaluate their firm's performance and its financial position. These ratios help to analyze current and past conditions, and are a starting point for future planning. In order to predict future development, it is necessary to monitor and analyze non-financial indicators; for example customer satisfaction, employee satisfaction, retention of high quality employees, and innovation grade. (Cerna, 2010) These indicators can help with the long-term prediction of company development by pointing to existing strengths, and to new opportunities for business.

5. For companies facing a decrease in sales, liquidity, access to credit, and are otherwise struggling to survive during the financial crisis, it is important to analyze and limit costs. This implies the elimination of unnecessary processes, which don't add to the produced value. At the same time, keeping the quality of products and services high is critical during the crisis. This factor may separate successful companies from troubled ones. The use of product norms, norms for quality management systems, and attitudes toward quality improvement are various ways of satisfying customer demands and enhancing the competitiveness of the enterprise. (Kucerova, 2008) SMEs can also revise supplier agreements, negotiate pricing, payment and delivery conditions; can optimize storing of materials and products, lower their number of employees, better manage working capital, strictly control direct costs, reevaluate fixed costs, use outsourcing.

\section{CONCLUSION}

By the end of last year, the gross domestic product (GDP) increased by $4,5 \%$ in the Slovak republic. There are predictions of positive development in GDP also for the year 2011. Based on this development, and also some other signs, there are hopes that the global financial and economical crisis is receding. SMEs, which survived the crisis need to recover and reestablish their pre-crisis market position. They need to implement a system of tools that will help them deal with current and future changes in business environment. We hope that our paper can be helpful in this process.

\section{REFERENCES}

Cerna, L. (2010). Business etiquette and its implementation in industrial enterprises in Slovak Republic, AlumniPress, ISBN 978-80-8096-110-7, Trnava

Fetisovova, E. et al. (2004). Finance of small and medium-sized enterprises, IURA EDITION, ISBN 80-89047-87-4, Bratislava

Kucerova, M. (2008). Improvement in Quality management system, In: Intercathedra, No 24. Poznan, ISSN 1640-3622, pp 49-50, 2008

*** (2010) http://www.nadsme.sk/files/Stav_MSP_2009_1.pdf, accessed on 2010-12-14

*** (2011) http://www.euractiv.sk/podnikanie-v-eu/zoznam liniek/kriza-a-male-a-stredne-podniky-000237, accessed on 2011-01-21 